\title{
Tarım sektöründe çalışan kadınların işe bakışları ve memnuniyetleri üzerine bir araştırma
}

\author{
A Research on the perspectives and satisfactions of women working in agriculture \\ sector
}

\author{
Mustafa Hakkı AYDOĞDU ${ }^{1}$ iD \\ ${ }^{1}$ Harran Üniversitesi Ziraat Fakültesi Tarım Ekonomisi Bölümü
}

\section{To cite this article:}

Aydoğdu, M.H. (2019). Tarım sektöründe çalışan kadınların işe bakışları ve memnuniyetleri üzerine bir araştırma. Harran Tarım ve Gıda Bilimleri Dergisi, 23(4): 380-390.

DOI:10.29050/harranziraat.555463

Address for Correspondence: Mustafa Hakkı AYDOĞDU e-mail:

mhaydogdu@hotmail.com

Received Date:

18.04.2019

Accepted Date:

17.09.2019

(C) Copyright 2018 by Harran University Faculty of Agriculture. Available on-line at www.dergipark.gov.tr/harranziraat
Öz

Kadınlar, her dönemde ekonomik ve toplumsal yaşamın önemli bir yanını oluşturmuştur. Tarım, ülkemizde kadınların oransal olarak en fazla istihdam edildiği sektördür. TRC2 Bölgesinde, Şanlıurfa ve Diyarbakır, tüm sektörlerde istihdam edilen kadınların \%59.2'isi, tarımda çalışmaktadır. Kadınlar tarımsal üretimin esas unsurları olup, çoğunlukla ücretsiz aile içi işgücü, gündelikçi ve mevsimlik tarım işçisi olarak, ağır koşullarda çalışmaktadırlar. Bu araştırmanın amacı Şanlıurfa'da tarımda çalışan kadınların tarım işçiliğine bakışları, memnuniyetleri ve beklentilerinin, medeni durum, eğitim ve yaş değişkenine bağlı olarak belirlenmesidir. Araştırma 2017 yılında, basit tesadüfi örnekleme yöntemiyle seçilen, kırsalda tarımda çalışan kadınlarla yüz yüze görüşmeler yoluyla anketler yapılmıştır. Örneklem hacmi \%95 güven sınırında ve \%5 hata payı ile belirlenmiştir. Analizler SPSS'de Ki-kare testi kullanılarak, 369 anket ile yapılmıştır. Elde edilen sonuçlara göre, katılımcının medeni durumu, eğitim seviyesi ve yaşı ile tarım işçiliğine bakışı ve düşünceleri, tarım işçisi olmaktan memnun olma durumu ve eğer tarım işçisi olmasıydı ne olmak veya yapmak isterdi değişkenleri arasında istatistiki olarak anlamlı bir ilgileşim tespit edilmiştir. Bunların istatistiki önem seviyesi p<\%1'dir. Bekâr olanlar, genç yaş grubunda yer alanlar ile ortaokul ve lise mezunları tarım işçiliğinden en fazla memnuniyetsizler olup, bunlar daha çok SGK'lı başka bir işte çalışmak istemektedirler. İleri yaş grubunda ve evli olanlar ise tarım işçiliğini kader olarak görmektedirler. Bunlar bölgenin ataerkil yapısı nedeniyle önce babalarına, sonra kocalarına ve sonrada erkek çocuklarına bağımlı kılınan kadınlardır. Kırsal da yaşayan ve çalışan kadınların, yaşam standartlarının yükseltilmesini sağlayacak, sosyal ve ekonomik yapılarının iyileştirilmesi ve arttırılmasına yönelik politikalar ve uygulamalar fazlalaştırılmalıdır.

Anahtar Kelimeler: Tarım işçiliği, Kadın işgücü, İş memnuniyeti, Kırsalda kadın beklentisi, Şanlıurfa

\section{ABSTRACT}

Women have always been an important part of economic and social life. In Turkey, agriculture is the sector where most women are employed. In TRC2 Region, 59.2\% of women employed in all sectors of Şanlıurfa and Diyarbakir work in agriculture. Women are the main elements of agricultural production and they work in severe conditions. The aim of this study is to determine the views, satisfaction and expectations of the women working in agriculture in Şanlıurfa based on the marital status, education and age variable. The surveys were conducted through face-to-face interviews with women working in rural agriculture, selected by simple random sampling method in 2017 . Sampling volume was determined by $95 \%$ confidence limit and $5 \%$ error margin. The analyzes were performed using the Chi-square test in SPSS with 369 questionnaires. According to the results, a statistically significant relationship was found between the participants' marital status, education level and age, their views and opinions on agricultural labor, their satisfaction with being agricultural workers, and what they wanted to be or would be if they were not agricultural workers with importance level of $p<1 \%$. The singles, the young age group and the middle and high school graduates are the most 
dissatisfied with agricultural labor, and they want to work in another job with social security. The older age group and married people who are dependent due to patriarchal status, see agricultural labor as destiny. Policies and practices for the improvement of socio-economic structures of women living in rural areas should be increased.

Key Words: Agricultural labor, Female labor force, Job satisfaction, Women expectancy in rural, Şanlıurfa

\section{Giriş}

İş ve çalışma, hayatın sürdürülebilir olması için yapılan bir faaliyettir. Çalışma hayatı, çalışanlara bir takım getiriler sağlamasının yanında, iş gününde yaşanan, iş ve çalışma koşullarından kaynaklanan, çeşitli duyguların birikimine de neden olmaktadır. İş memnuniyeti, kişisel olup, bireylere göre farklılıklar göstermekle birlikte, çalışanların yaptıkları işlerden ve iş ortamından etkilenme durumuna bağlı olarak şekillenmektedir (Eğinli, 2009). Yani, çalışanların yaptıkları işle ilgili yaşanmışların ve duygusal tepkilerinin bir toplamıdır. Son dönemlerde yaşam memnuniyeti ile iş memnuniyeti birbirini ilgilendiren, tamamlayan, anlamlandıran ve etkileyen iki kavram olarak anılmaya başlanmıştır. Çalışanlar zamanlarının önemli bir bölümünü iş yerlerinde ve iş ortamlarında geçirmekte, burada yaşadıkları memnuniyetleri ve memnuniyetsizlikleri, iş yaşamı dışındaki zamanlarını da olumlu ya da olumsuz yönde etkileyebilmektedir. Diğer taraftan, bunun tersi de mümkündür. $\mathrm{Bu}$ bakımdan, iş ve yaşam, birbirinin içerisine geçecek kadar bir bütünü oluşturmakta ve birbirini anlamlandırmaktadır (Dikmen, 1995: 115).

Tarım toplumundan, bilgi toplumuna kadar olan tüm süreçlerde, sorumluluk alanları farklı olsa da kadınlar, her dönemde ekonomik ve toplumsal yaşamın önemli bir yanını oluşturmuştur (Pınar, 2008: 86). Toplumsal refahın tabana yayılması ve sürdürülebilir büyümenin gerçekleşebilmesi için, işgücü piyasalarında kadınların eşit koşullarda yer alması, ekonomik ve sosyal kalkınmanın vazgeçilmez elemanları olarak kabul edilmesinden geçmektedir (Peker ve Kubar, 2012).

Ülkelerin gelişmişlik göstergelerinden biri de, istihdamın sektörel ve cinsiyet temelli dağılımlarıdır. Gelişmiş ülkelerde, sanayi ve hizmetler sektöründe istihdam artarken, tarım sektöründe ise azalmaktadır (Biçerli, 2000: 135). $\mathrm{Bu}$ durum kuruluşundan günümüze kadar, genel olarak ülkemiz içinde geçerli olmakla birlikte, halen tarımın payı, özellikle de kadın çalışanlar açısından, büyüktür (Berber ve Eser, 2008).

Gelişmişlik seviyeleri ne olursa olsun, tarım her ülke için stratejik bir öneme sahiptir. Tarım, Türkiye ekonomisinde halen büyük önem arz eden bir sektör konumundadır. Tarımın birçok öneminin yanında, nüfusun gıda güvenliği ve istihdam sağlaması açısından ayrıca bir önemi vardır. Kadınlar, çalışma yaşamı içerisinde çeşitli niteliklerdeki işlerde çalışırken bir yandan da kendilerinden beklenen toplumsal cinsiyet rollerine de uygun davranmaya çalışmaktadırlar (Ünüvar ve Tagay, 2015).

Tarımsal üretim ve gıda konularında, ailelere ekonomik katkı sağlanmasında, ev içi ve dışı rolleri yerine getiren, kırsalda yaşam koşullarının iyileşmesine katkı sağlayan kadınlar, kayıt dışılık, sosyal güvenlikten yoksun olma, girişimci olamama, ağır koşullarda ve emek-yoğun işlerde, diğer çalışanlara göre düşük ücretle çalışmaları nedeniyle toplumun en dezavantajlı gruplarından birini oluşturmaktadır (Gülçubuk, 2017).

Hane halkı işgücü araştırması sonuçlarına göre; 2016 yılında, Türkiye'de 15 ve daha yukarı yaştaki istihdam edilenlerin oranı $\% 46.3$ olup, bu oran erkeklerde \%65.1, kadınlarda ise \%28'dir. Cinsiyete ve ekonomik faaliyetlere göre istihdam oranı açısından, tarım sektöründe toplam istihdam \%19.5 olup, erkeklerin istihdam oranı \%15.5 iken, kadınların istihdam oranı ise \%28.7' dir (TUiK, 2018a).

Türkiye'de tarımın sektörel işgücü içindeki payı 2017 yılında \%19.4 iken, 2018 yılı ilk 11 ay içindeki payı ise \%18.54 olarak gerçekleşmiş olup, 5.34 milyon kişi tarımda istihdam edilmektedir (TUiK, 2019a). 2017 yılında Türkiye'de tarımda çalışanların \%45.2'isi kadınlardan oluşmakta ve cinsiyete dayalı sektörel temelli istihdamda, tarım 
kadınların en fazla istihdam edildiği sektör konumundadır (TUiK, 2019b). Bir başka deyişle, kadınlar tarımsal üretimin esas unsurları olup, çoğunlukla ücretsiz aile içi işgücü, gündelikçi ve mevsimlik tarım işçisi olarak çalışmaktadırlar. TRC2 Bölgesi olan Şanlıurfa ve Diyarbakır'da, 2017 yılında tüm sektörlerde istihdam edilen kadınların sayısı 268 bin olup, bunların 159 bini yani \%59.2'si, tarımda çalışmaktadır (TUiK, 2019b).

$\mathrm{Bu}$ çalışma, geniş kapsamlı olarak yapılan bir araştırmanın parçası olup, amacı Şanlıurfa'da tarımda çalışan kadınların tarım işçiliğine bakışları, memnuniyetleri ve beklentilerinin, medeni durum, eğitim ve yaş değişkenine bağlı olarak belirlenmesidir.

\section{Materyal ve Yöntem}

Şanlıurfa'nın 2017 yılında nüfusu 1,985,753 kişi olup, bunun 986,454'ü kadınlardan oluşmaktadır (TUiK, 2018b). Bu çalışmanın esas materyalini Şanlıurfa'da tarımda çalışan kadınlarla yapılan görüşmelerden elde edilen veriler oluşturmaktadır. Anketler, basit tesadüfi örnekleme yöntemiyle seçilen ve anket yapmayı kabul eden kadınlarla, yüz yüze görüşmeler yoluyla 2017 yılında yapılmıştır. Anketörlerin tamamı yerel dilleri konuşabilen, anket yapılan sahada bilinirliği olan ve ağırlıklı olarak bayanlardan oluşturulmuştur. Örneklem hacmi, ana kütle büyüklükleri ve tolerans gösterilebilir örneklem hatasına göre örneklem hacimleri tablosundan, \%95 güven düzeyinde ve $\% 5$ hata payı ile belirlenmiştir (Bayram, 2015: 26). Buna göre örneklem hacmi 384 olmaktadır. Sahada yapılan anketlerden 15 tanesinin yarım, eksik, tutarsız vb. olması nedeniyle, analizlerde 369 anket kullanılmıştır.

Elde edilen veriler Excele belirli bir kod planı ile işlenmiş olup, daha sonra SPSS'de analiz edilmiştir. Analizlerde Ki-kare testi kullanılmış olup, bu analiz sık kullanılan parametrik olmayan testlerden biridir. Ki-Kare testi, gözlenen ile beklenen değerler arasındaki farkın, istatistiksel olarak anlamlı olup, olmadığının belirlenmesinde kullanılır (Orhunbilge, 2000: 248; Lorcu, 2015: 179).

\section{Araştırma Bulguları ve Tartışma}

Ankete katılanların \%82'si evli, \%31'i okuryazar değil, \%50'si ilkokul ve altı mezunu, hane halkı ortalaması 7 ve yaş ortalaması 35.6'dır.

Analizlerde medeni durum, eğitim seviyesi ve yaş bağımsız değişkenler olarak alınmıştır. Bağımsız değişkenler, kırsal ve kent yaşamında kadın çalışanların hem işgücüne katılma oranlarını ve hem de iş memnuniyetini etkileyen önemli faktörler arasında olması nedeniyle seçilmiştir. Bu seçimde, Tüik'in hane halkı işgücü verileri de belirleyici olmuştur. Son dönemlerde yapılan birçok çalışmada, seçilen bağımsız değişkenlerin, kadınların işgücüne katılımlarında, yaşam ve iş memnuniyetlerinde etkili faktörler olduğu tespit edilmiştir (Başlevent ve Onaran, 2003; Kızılgöl, 2012; Kılıç ve Öztürk, 2014; Yazıcı, 2018).

Bağımlı değişkenler ise tarım işçiliği hakkındaki düşünceleri (düşünce), tarım işçisi olmaktan memnun olma durumu (memnuniyet) ve eğer tarım işçisi olmasıydı ne olmak veya yapmak isterdi (beklenti) olarak belirlenmiştir. Anketlerden elde edilen bağımlı ve bağımsız değişkenlere ilişkin frekans dağılımları Çizelge 1'de verilmiştir.

Katılımcıların medeni durumu ile tarım işçiliğine ilişkin düşünceleri arasındaki ki-kare test sonuçları Çizelge 2'de verilmiştir. Sonuçlara göre medeni durum ile düşünceleri arasında istatistiki olarak bir anlamlılık mevcut olup, önem derecesi $p<\% 1^{\prime}$ dir. 
Çizelge 1. Değişkenlere ilişkin frekans dağılımları

Table 1. Frequency distributions for variables

\begin{tabular}{|c|c|c|c|c|c|}
\hline \multicolumn{3}{|c|}{$\begin{array}{l}\text { Bağımsız Değişkenler } \\
\text { Independent Variables }\end{array}$} & \multicolumn{3}{|c|}{$\begin{array}{l}\text { Bağımlı Değişkenler } \\
\text { Dependent Variables }\end{array}$} \\
\hline $\begin{array}{l}\text { Medeni Durum } \\
\text { Marital Status }\end{array}$ & $\begin{array}{l}\text { Frekans } \\
\text { Frequency }\end{array}$ & $\%$ & $\begin{array}{l}\text { Düşünce } \\
\text { Thought }\end{array}$ & $\begin{array}{l}\text { Frekans } \\
\text { Frequency }\end{array}$ & $\%$ \\
\hline $\begin{array}{l}\text { Bekâr } \\
\text { Evli } \\
\text { Dul }\end{array}$ & $\begin{array}{c}50 \\
303 \\
16\end{array}$ & $\begin{array}{c}13.6 \\
82.1 \\
4.3\end{array}$ & $\begin{array}{l}\text { Koşullar zor-ücret az } \\
\text { Yapacak başka iş yok } \\
\text { Kader-Elimde değil }\end{array}$ & $\begin{array}{l}130 \\
135 \\
104\end{array}$ & $\begin{array}{l}35.2 \\
36.6 \\
28.2\end{array}$ \\
\hline $\begin{array}{l}\text { Eğitim Seviyesi } \\
\text { Education Level }\end{array}$ & $\begin{array}{l}\text { Frekans } \\
\text { Frequency }\end{array}$ & $\%$ & $\begin{array}{l}\text { Memnuniyet } \\
\text { Satisfaction }\end{array}$ & $\begin{array}{l}\text { Frekans } \\
\text { Frequency }\end{array}$ & $\%$ \\
\hline $\begin{array}{l}\text { Okuryazar değil } \\
\text { Okuryazar } \\
\text { ilkokul } \\
\text { Ortaokul } \\
\text { Lise }\end{array}$ & $\begin{array}{c}113 \\
106 \\
80 \\
56 \\
14\end{array}$ & $\begin{array}{c}30.6 \\
28.7 \\
21.7 \\
15.2 \\
3.8\end{array}$ & $\begin{array}{c}\text { Hayır } \\
\text { Evet } \\
\text { Kader-Elimde değil }\end{array}$ & $\begin{array}{c}172 \\
82 \\
115\end{array}$ & $\begin{array}{l}46.6 \\
22.2 \\
31.2\end{array}$ \\
\hline $\begin{array}{l}\text { Yaş } \\
\text { Age }\end{array}$ & $\begin{array}{l}\text { Frekans } \\
\text { Frequency }\end{array}$ & $\%$ & $\begin{array}{c}\text { Beklenti } \\
\text { Expectation }\end{array}$ & $\begin{array}{l}\text { Frekans } \\
\text { Frequency }\end{array}$ & $\%$ \\
\hline $\begin{array}{c}18-29 \\
30-39 \\
40-49 \\
50 \text { ve üzeri }\end{array}$ & $\begin{array}{c}138 \\
86 \\
91 \\
54\end{array}$ & $\begin{array}{l}37.4 \\
23.3 \\
24.7 \\
14.6\end{array}$ & $\begin{array}{c}\text { Sadece ev hanımı olmak } \\
\text { SGK'lı başka bir işte çalışmak } \\
\text { Hiç düşünmedim }\end{array}$ & $\begin{array}{c}145 \\
134 \\
90\end{array}$ & $\begin{array}{l}39.3 \\
36.3 \\
24.4\end{array}$ \\
\hline $\begin{array}{l}\text { Toplam } \\
\text { Total }\end{array}$ & 369 & 100.0 & $\begin{array}{l}\text { Toplam } \\
\text { Total }\end{array}$ & 369 & 100.0 \\
\hline
\end{tabular}

Çizelge 2. Medeni durum ile tarım işleri hakkındaki düşüncelerinin test istatistiği

Table 2. Test data on marital status and opinions on agricultural works

\begin{tabular}{|c|c|c|c|c|c|}
\hline \multirow{2}{*}{\multicolumn{2}{|c|}{$\begin{array}{l}\text { Medeni Durum } \\
\text { Marital Status }\end{array}$}} & \multicolumn{3}{|c|}{$\begin{array}{l}\text { Tarım işçiliği hakkındaki düşünceleri } \\
\text { Thoughts on agricultural laborships }\end{array}$} & \multirow{2}{*}{$\begin{array}{l}\text { Toplam } \\
\text { Total }\end{array}$} \\
\hline & & Koşullar zor-ücret az & Yapacak başka iş yok & Kader & \\
\hline $\begin{array}{l}\text { Bekâr } \\
\text { Single }\end{array}$ & $\begin{array}{l}\text { Gözlenen frekans } \\
\text { Beklenen frekans }\end{array}$ & $\begin{array}{c}24 \\
17.6\end{array}$ & $\begin{array}{c}26 \\
18.3\end{array}$ & $\begin{array}{c}0 \\
14.1\end{array}$ & $\begin{array}{c}50 \\
50.0\end{array}$ \\
\hline $\begin{array}{l}\text { Evli } \\
\text { Married }\end{array}$ & $\begin{array}{l}\text { Gözlenen frekans } \\
\text { Beklenen frekans }\end{array}$ & $\begin{array}{c}100 \\
106.7\end{array}$ & $\begin{array}{c}99 \\
110.9\end{array}$ & $\begin{array}{l}104 \\
85.4\end{array}$ & $\begin{array}{c}303 \\
303.0\end{array}$ \\
\hline $\begin{array}{l}\text { Dul } \\
\text { Widow }\end{array}$ & $\begin{array}{l}\text { Gözlenen frekans } \\
\text { Beklenen frekans }\end{array}$ & $\begin{array}{c}6 \\
5.6\end{array}$ & $\begin{array}{l}10 \\
5.9\end{array}$ & $\begin{array}{c}0 \\
4.5\end{array}$ & $\begin{array}{c}16 \\
16.0\end{array}$ \\
\hline $\begin{array}{l}\text { Toplam } \\
\text { Total }\end{array}$ & $\begin{array}{l}\text { Gözlenen frekans } \\
\text { Beklenen frekans }\end{array}$ & $\begin{array}{c}130 \\
130.0\end{array}$ & $\begin{array}{c}135 \\
135.0\end{array}$ & $\begin{array}{c}104 \\
104.6\end{array}$ & $\begin{array}{c}369 \\
369.0\end{array}$ \\
\hline \multicolumn{2}{|c|}{$\begin{array}{l}\text { Ki-Kare Testi } \\
\text { Chi-Square Test }\end{array}$} & $\begin{array}{l}\text { Değer } \\
\text { Value }\end{array}$ & df & \multicolumn{2}{|c|}{$\begin{array}{l}\text { p değeri } \\
p \text { value }\end{array}$} \\
\hline \multirow{3}{*}{\multicolumn{2}{|c|}{$\begin{array}{l}\text { Pearson Chi-Square } \\
\text { Likelihood Ratio } \\
\text { Linear-by-Linear Association } \\
\mathrm{N} \text { of Valid Cases }\end{array}$}} & 32.870 & 4 & \multicolumn{2}{|c|}{0.000} \\
\hline & & 50.126 & 4 & \multicolumn{2}{|c|}{0.000} \\
\hline & & $\begin{array}{c}6.139 \\
369\end{array}$ & 1 & \multicolumn{2}{|c|}{0.013} \\
\hline
\end{tabular}

Çizelge 3. Medeni durum ile tarım işçisi olmaktan memnun olma durumu test istatistiği

Table 3. Test statistics of marital status and satisfaction of being an agricultural worker

\begin{tabular}{|c|c|c|c|c|c|}
\hline \multirow{2}{*}{\multicolumn{2}{|c|}{$\begin{array}{l}\text { Medeni Durum } \\
\text { Marital Status }\end{array}$}} & \multicolumn{3}{|c|}{$\begin{array}{l}\text { Tarım işçisi olmaktan memnun olma durumu } \\
\text { Satisfaction with being an agricultural worker }\end{array}$} & \multirow{3}{*}{$\begin{array}{c}\text { Toplam } \\
\text { Total } \\
50 \\
50.0\end{array}$} \\
\hline & & \multirow{2}{*}{$\begin{array}{c}\text { Hayır } \\
50 \\
23.3\end{array}$} & \multirow{2}{*}{$\begin{array}{c}\text { Evet } \\
0 \\
11.1\end{array}$} & \multirow{2}{*}{$\begin{array}{c}\text { Kader } \\
0 \\
15.6\end{array}$} & \\
\hline $\begin{array}{l}\text { Bekâr } \\
\text { Single }\end{array}$ & $\begin{array}{l}\text { Gözlenen frekans } \\
\text { Beklenen frekans }\end{array}$ & & & & \\
\hline $\begin{array}{l}\text { Evli } \\
\text { Married }\end{array}$ & $\begin{array}{l}\text { Gözlenen frekans } \\
\text { Beklenen frekans }\end{array}$ & $\begin{array}{c}115 \\
141.2\end{array}$ & $\begin{array}{c}76 \\
67.3\end{array}$ & $\begin{array}{l}112 \\
94.4\end{array}$ & $\begin{array}{c}303 \\
303.0\end{array}$ \\
\hline $\begin{array}{l}\text { Dul } \\
\text { Widow }\end{array}$ & $\begin{array}{l}\text { Gözlenen frekans } \\
\text { Beklenen frekans }\end{array}$ & $\begin{array}{c}7 \\
7.5\end{array}$ & $\begin{array}{c}6 \\
3.6\end{array}$ & $\begin{array}{c}3 \\
5.0\end{array}$ & $\begin{array}{c}16 \\
16.0\end{array}$ \\
\hline $\begin{array}{l}\text { Toplam } \\
\text { Total }\end{array}$ & $\begin{array}{l}\text { Gözlenen frekans } \\
\text { Beklenen frekans }\end{array}$ & $\begin{array}{c}172 \\
172.0\end{array}$ & $\begin{array}{c}82 \\
82.0\end{array}$ & $\begin{array}{c}115 \\
115.0\end{array}$ & $\begin{array}{c}369 \\
369.0\end{array}$ \\
\hline \multicolumn{2}{|c|}{$\begin{array}{l}\text { Ki-Kare Testi } \\
\text { Chi-Square Test }\end{array}$} & $\begin{array}{l}\text { Değer } \\
\text { Value }\end{array}$ & $d f$ & \multicolumn{2}{|c|}{$\begin{array}{c}\mathrm{p} \text { değeri } \\
p \text { value }\end{array}$} \\
\hline \multicolumn{2}{|c|}{$\begin{array}{l}\text { Pearson Chi-Square } \\
\text { Likelihood Ratio } \\
\text { Linear-by-Linear Association } \\
\mathrm{N} \text { of Valid Cases }\end{array}$} & $\begin{array}{c}69.025 \\
88.034 \\
34.937 \\
369 \\
\end{array}$ & $\begin{array}{l}4 \\
4 \\
1\end{array}$ & \multicolumn{2}{|c|}{$\begin{array}{l}0.000 \\
0.000 \\
0.000\end{array}$} \\
\hline
\end{tabular}


Tarım işçiliğini başka bir iş olmadığı için yaptığını söyleyenlerin oranı $\% 36.6$ 'dır. Bunu \%35.2 ile koşullar zor ve ücreti az seçeneği ve \%28.2 ile kader, elimde değil diyenler takip etmektedir. Burada dikkat çeken sonuç sadece evli olanların, tarım işçiliğini elinde olan bir seçenek olarak görmeyip, başka bir ifade ile zorunluluk ve kader olarak kabul etmeleridir. Burada belirleyici olan kocadır. Bekâr ve dul olanlar, iş seçme yönünden, evlilere göre daha fazla seçenek sahibidirler. Katılımcıların medeni durumu ile tarım işçisi olmaktan memnun olma durumları arasındaki ki-kare test sonuçları Çizelge 3'de verilmiştir. Buna göre medeni durum ile memnuniyet arasında istatistiki olarak bir anlamlılık mevcut olup, önem derecesi $p<\% 1$ 'dir.

Katılımcıların \%46.6'sı tarım işçisi olmaktan memnun değildir. Bir başka değişle iş ve çalışma memnuniyeti yoktur. Memnun olanların oranı \%22.2'dir. Burada dikkat çeken sonuç bekârlarda ortaya çıkmakta olup, tamamı tarımda çalışmaktan memnun değildir. Bir başka dikkat çeken sonuç ise evli olanların tarım işçiliğine en fazla "kader" yanıtı veren grubu oluşturmasıdır. İş memnuniyeti ile yaşam memnuniyeti arasında, ya da tam tersi, doğrusal bir ilişki vardır. Ülkemizde tarım işçilerinin çalışma koşulları birçok açıdan oldukça yetersiz olup, bu durum onların yaşam düzeylerini olumsuz olarak etkilemektedir (Özbekmezci ve Sahil, 2004). Katılımcıların medeni durumu ile eğer tarım işçisi olmasıydı ne olmak veya yapmak isterdi (beklenti) arasındaki ki-kare test sonuçları Çizelge 4'de verilmiştir. Buna göre medeni durum ile beklenti arasında istatistiki olarak bir anlamlılık mevcut olup, önem derecesi $\mathrm{p}<\% 1^{\prime}$ dir.

Çizelge 4. Medeni durum ile beklenti arasındaki test istatistiği

Table 4. Test statistics between marital status and expectation

\begin{tabular}{|c|c|c|c|c|c|}
\hline \multirow{2}{*}{\multicolumn{2}{|c|}{$\begin{array}{l}\text { Medeni Durum } \\
\text { Marital Status }\end{array}$}} & \multicolumn{3}{|c|}{$\begin{array}{c}\text { Eğer tarım işçisi olmasıydı ne olmak ya da yapmak isterdi } \\
\text { What would you want to be or not if you were not an agricultural } \\
\text { worker }\end{array}$} & \multirow[b]{2}{*}{ ToplamTotal } \\
\hline & & Sadece ev hanımı olmak & $\begin{array}{c}\text { SGK'lı başka bir işte } \\
\text { çalışmak }\end{array}$ & Hiç düşünmedim & \\
\hline $\begin{array}{l}\text { Bekâr } \\
\text { Single }\end{array}$ & $\begin{array}{l}\text { Gözlenen frekans } \\
\text { Beklenen frekans }\end{array}$ & $\begin{array}{c}0 \\
19.6\end{array}$ & $\begin{array}{c}50 \\
18.2 \\
\end{array}$ & $\begin{array}{c}0 \\
12.2 \\
\end{array}$ & $\begin{array}{c}50 \\
50.0 \\
\end{array}$ \\
\hline $\begin{array}{l}\text { Evli } \\
\text { Married }\end{array}$ & $\begin{array}{l}\text { Gözlenen frekans } \\
\text { Beklenen frekans }\end{array}$ & $\begin{array}{c}141 \\
119.1 \\
\end{array}$ & $\begin{array}{c}78 \\
110.0 \\
\end{array}$ & $\begin{array}{c}84 \\
73.4 \\
\end{array}$ & $\begin{array}{c}303 \\
303.0 \\
\end{array}$ \\
\hline $\begin{array}{l}\text { Dul } \\
\text { Widow }\end{array}$ & $\begin{array}{l}\text { Gözlenen frekans } \\
\text { Beklenen frekans }\end{array}$ & $\begin{array}{c}4 \\
6.3 \\
\end{array}$ & $\begin{array}{c}6 \\
5.8 \\
\end{array}$ & $\begin{array}{c}6 \\
3.9 \\
\end{array}$ & $\begin{array}{c}16 \\
16.0 \\
\end{array}$ \\
\hline $\begin{array}{l}\text { Toplam } \\
\text { Total }\end{array}$ & $\begin{array}{l}\text { Gözlenen frekans } \\
\text { Beklenen frekans }\end{array}$ & $\begin{array}{c}145 \\
145.0 \\
\end{array}$ & $\begin{array}{c}134 \\
134.0 \\
\end{array}$ & $\begin{array}{c}90 \\
90.0\end{array}$ & $\begin{array}{c}369 \\
369.0 \\
\end{array}$ \\
\hline \multicolumn{2}{|c|}{$\begin{array}{l}\text { Ki-Kare Testi } \\
\text { Chi-Square Test }\end{array}$} & $\begin{array}{l}\text { Değer } \\
\text { Value }\end{array}$ & df & \multicolumn{2}{|c|}{$\begin{array}{c}\text { p değeri } \\
p \text { value }\end{array}$} \\
\hline \multicolumn{2}{|c|}{$\begin{array}{l}\text { Pearson Chi-Square } \\
\text { Likelihood Ratio } \\
\text { Linear-by-Linear Association } \\
\mathrm{N} \text { of Valid Cases }\end{array}$} & $\begin{array}{c}104.398 \\
118.750 \\
0.243 \\
369\end{array}$ & $\begin{array}{l}4 \\
4 \\
1\end{array}$ & \multicolumn{2}{|c|}{$\begin{array}{l}0.000 \\
0.000\end{array}$} \\
\hline
\end{tabular}

Katılımcıların \%39.3'ü çalışmak istememekte ve sadece ev hanımı olmak istemektedir. Sosyal Güvenlik Kapsamında (SGK) tarım dışında başka bir işte çalışmak isteyenlerin oranı $\% 36.3$ ve hiç düşünmedim diyenlerin oranı ise \%24.4'dür. Burada dikkat çeken sonuçlar arasında bekârların hiç birinin sadece ev kadını olmak gibi bir beklentisi olmayıp, katılımcıların tamamının SGK'lı başka bir işte çalışmak istemeleridir. Evli kadınların \%46.6'sı sadece ev hanımı olmak isterken, \%27.7'si ise hiç düşünmediğini ki, bu seçenek aslında kader ve seçim yapmak elimde değil demek, sonucunu vermektedir. Ülkemizde tarımda çalışan kadınların \%78'i ücretsiz aile iş̧̧isi olup, \%90 civarı kayıt dışı ve SGK kapsamında olmadan, sosyal güvenlik haklarından yoksun olarak çalışmaktadır (Gülçubuk, 2017; TZOB, 2018).

Toplumsal kalkınmanın temel taşlarından biri olan kadınların, kırsal da yaşam şartları daha da 
zordur. Kırsalda kadınlar evde, avluda, ahırda, tarlada günde ortalama 16 saat çalışan, ürettiği değerler onlardan beklenen şeyler olduğu için, erkeklere göre daha az değerli, çoğu kez değersiz kabul edilen, daha az söz hakkına sahip olan, önce babalarına, sonra kocalarına ve daha sonra da erkek çocuklarına bağımlı yapılan kadınlar, kırsaldaki en dezavantajlı grupların başında gelmektedir (Arıkan, 1988; Gökdemir ve Ergün, 2012; TZOB, 2018).

$\mathrm{Bu}$ çalışmanın ikinci bağımsız değişkeni olan eğitimde, ankete katılanlar arasında yüksekokul mezunu yoktur, eğitim seviyesi ile tarım işçiliğine ilişkin düşünceleri arasındaki ki-kare test sonuçları Çizelge 5'de verilmiştir. Buna göre eğitim seviyesi ile düşünceleri arasında istatistiki olarak bir anlamlılık mevcut olup, önem derecesi $p<\% 1$ 'dir. Buna göre tarım işçiliğini kader olarak görenlerin oranı \%28.2'dir. Eğitim seviyesi arttıkça işçiliği kader olarak görenlerin oranı azalmaktadır. Tarım işçiliğini, koşulları zor ve ücreti az olarak görenler ile yapacak başka bir iş yok diyenlerin oranı aynı olup, \%35.2'dir. Katılımcılar arasındaki en yüksek eğitim seviyesi lise olup, bu grubun tamamı tarım işçiliğini, yapacak başka bir iş olmadığı için, yaptıklarını belirtmişlerdir.

Çizelge 5. Eğitim seviyesi ile tarım işleri hakkındaki düşüncelerinin test istatistiği

Table 5. The level of education and the statistics of the thoughts on agricultural jobs

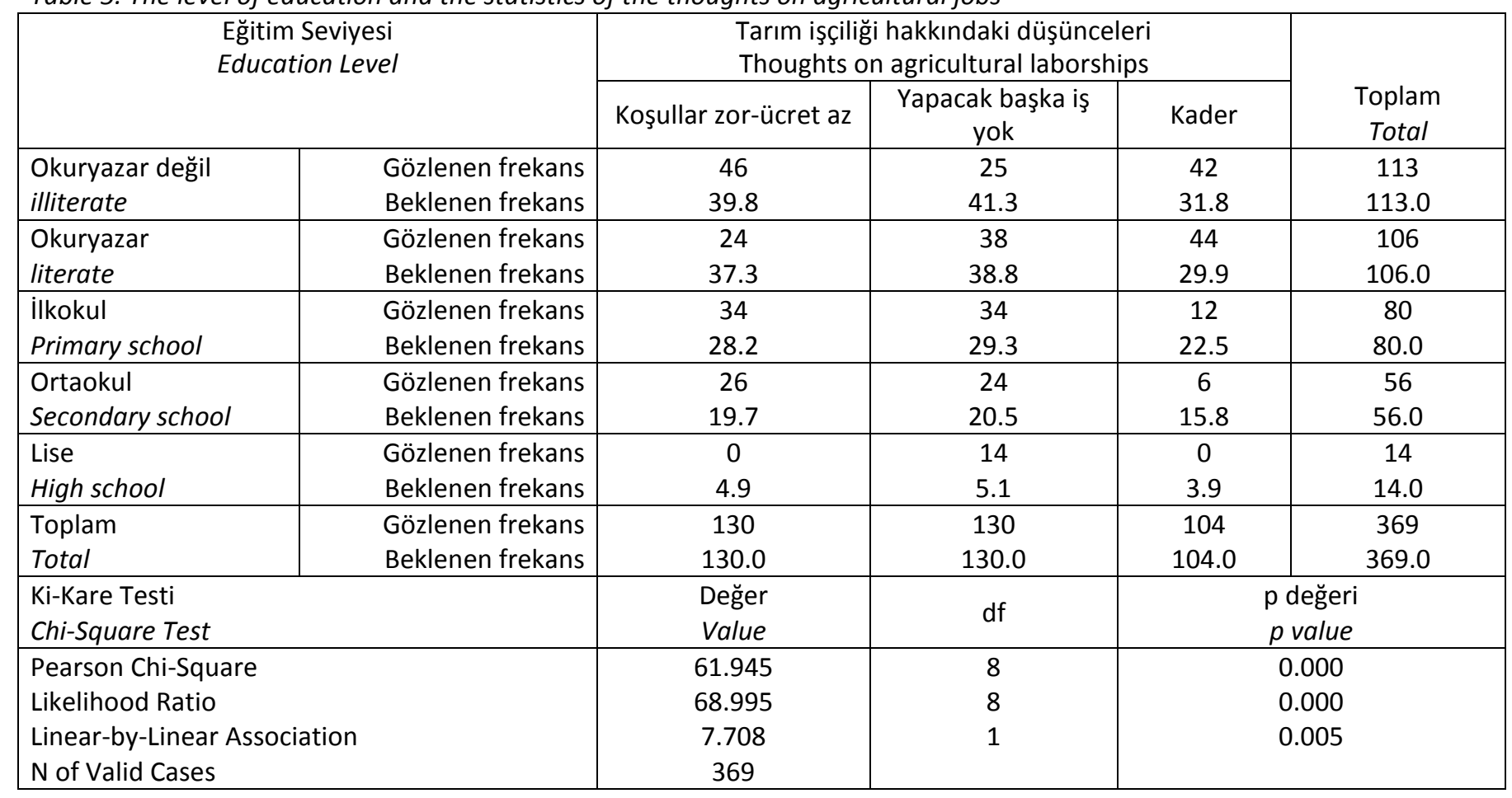

Katılımcıların eğitim seviyesi ile tarım işçisi olmaktan memnun olma durumları arasındaki kikare test sonuçları Çizelge $6^{\prime}$ da verilmiştir. Buna göre eğitim durum ile memnuniyet arasında istatistiki olarak bir anlamlılık mevcut olup, önem derecesi $p<\% 1$ 'dir.

Tarım işçisi olmaktan memnun olanların oranı $\% 22.2$ ve memnun olmayanların oranı ise \%46.6'dır. Bir başka deyişle katılımcıların neredeyse yarısı, tarımda çalışmaktan ve işçilik yapmaktan memnun değildir. İşçiliği kader olarak görenlerin oranı ise \%31.2 olup, bunların \%94.8'i ilkokul ve altında eğitim alanlardır. Yine en yüksek eğitim grubu olan lise mezunlarının tamamı memnun değildir.

Eğitim seviyesi ile memnuniyet arasında ters yönde istatistiki bir ilişki mevcut olup, eğitim seviyesi arttıkça memnuniyet azalmaktadır. Eğitim, nitelikli iş gücü, insani gelişme, sosyal refah ve kalkınmada önemli bir unsur olup (Günkör, 2017), eğitim seviyesi arttıkça, bireyler daha iyi bir yaşam istemektedir.

Katılımcıların eğitim durumu ile eğer tarım işçisi olmasıydı ne olmak veya yapmak isterdi arasındaki ki-kare test sonuçları Çizelge $7^{\prime}$ de verilmiştir. Buna göre eğitim durum ile beklenti arasında istatistiki olarak bir anlamlılık mevcut olup, önem derecesi $p<\% 1$ 'dir. 
Çizelge 6. Eğitim durumu ile tarım iş̧̧isi olmaktan memnun olma durumu test istatistiği

Table 6. Test statistics of education level and satisfaction of being an agricultural worker

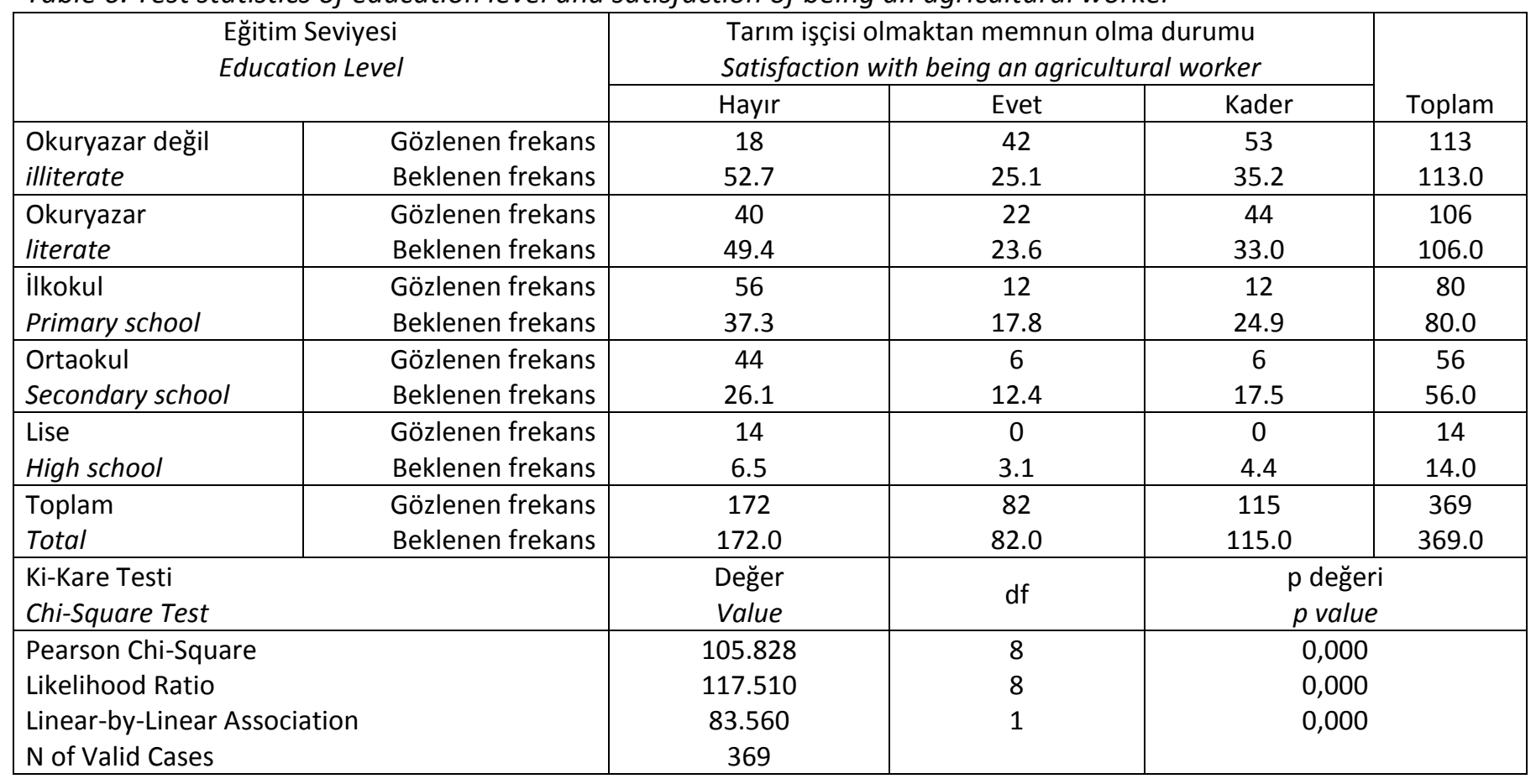

Katılımcıların \%39.3'ü sadece ev hanımı olmak isterken, \%36.3'ü SGK'lı başka bir işte çalışmak istediklerini ve \%24.4'ü ise bunu hiç düşünmediklerini belirtmişlerdir. Hiç düşünmediklerini belirtenlerin tamamı ilkokul ve altı eğitimi alanlardır. Eğitim seviyesi arttıkça, SGK'lı işte çalışma beklentisi ve istediği de artmaktadır. Lise mezunlarının tamamı SGK'lı başka bir işte çalışmak istediklerini belirtmişlerdir.

Eğitim seviyesi arttıkça kırsal da yaşamak isteği azalmakta, daha iyi bir işte, SGK kapsamında çalışma beklentisi artmaktadır. Eğitim seviyesi ile daha iyi bir gelir, teknoloji kullanımı ve sosyal refah arasında ki bu durum toplumsal refahı da olumlu etkileyebilecek yönde olup, doğrusal bir ilişki vardır (Günkör, 2017).

Çizelge 7. Eğitim durumu ile beklenti arasındaki test istatistiği Table 7. Test statistic between education level and expectation

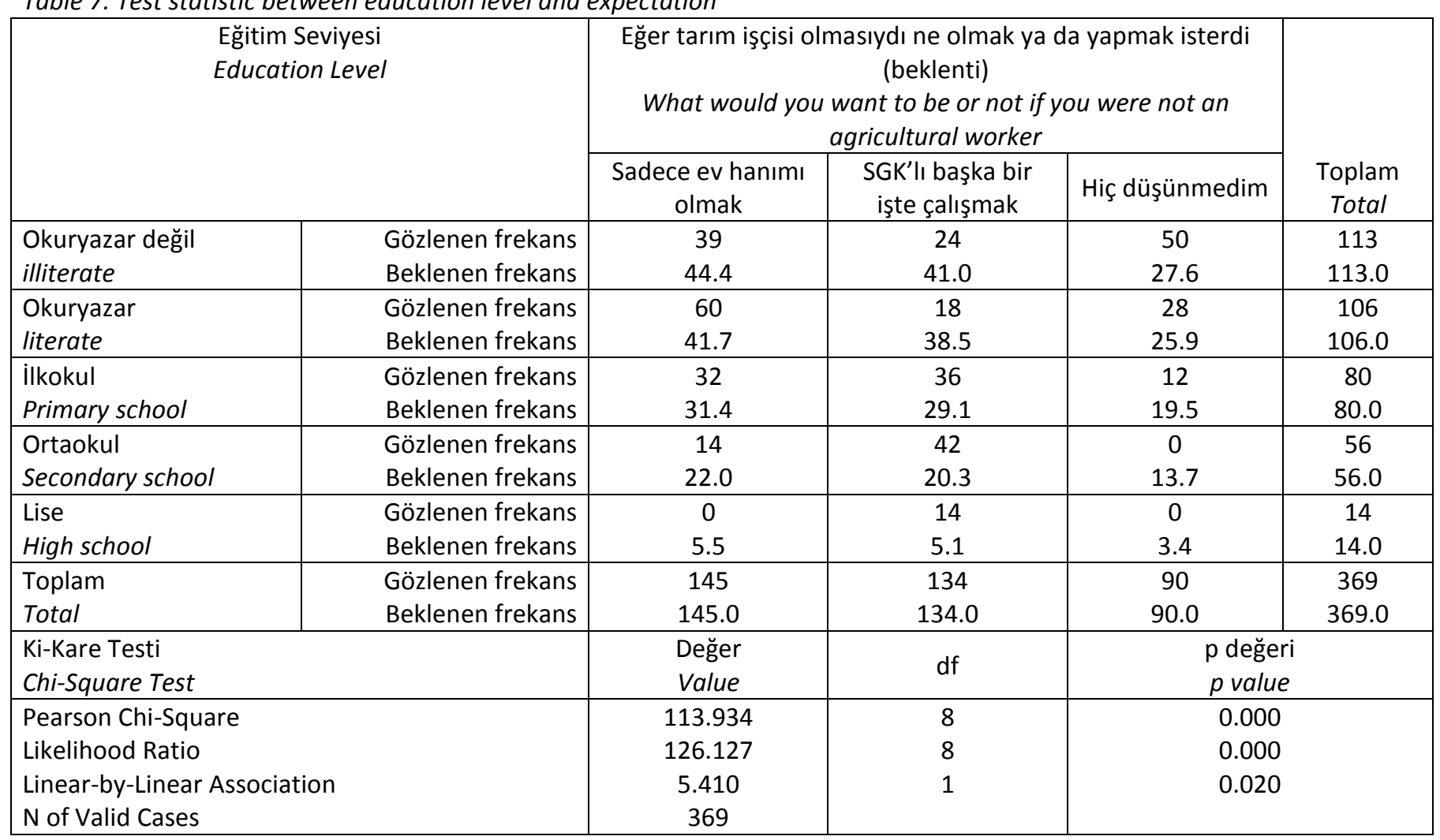


Bu çalışmanın üçüncü bağımsız değişkeni olan ki-kare test sonuçları Çizelge 8'de verilmiştir. yaş ile tarım iş̧̧iliğine ilişkin düşünceleri arasındaki

Çizelge 8. Yaş ile tarım işleri hakkındaki düşüncelerinin test istatistiği

Table 8. Test statistics on the thoughts about agriculture with age

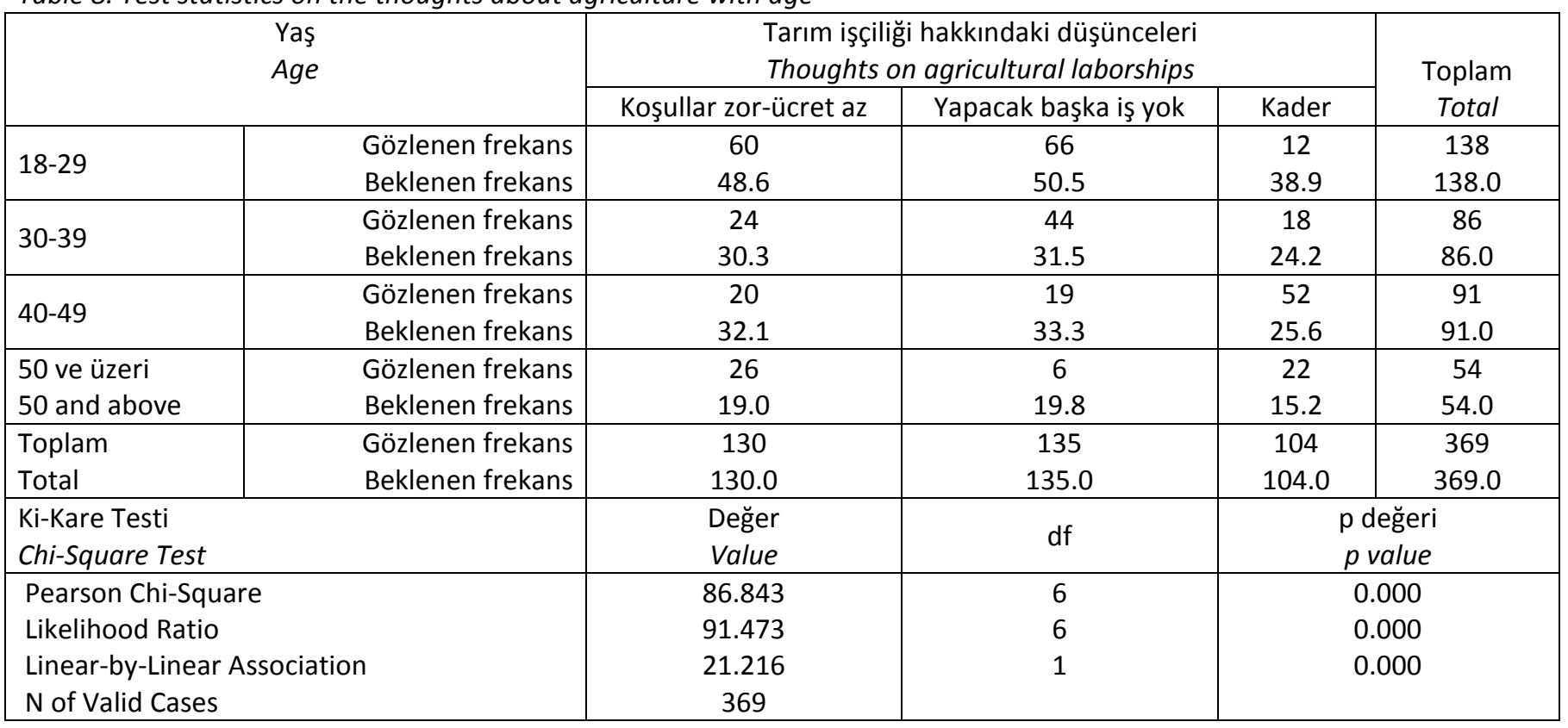

Çizelge 8'deki sonuçlara göre yaş ile düşünceleri arasında istatistiki olarak bir anlamlılık mevcut olup, önem derecesi $p<\% 1$ 'dir. Katılımcıların \%36.6'sı yapacak başka bir iş olmadığını, \%35.2'si koşullarının zor ve ücretinin az olduğunu belirtirken, \%28.2'si de tarım işçiliğini kader olarak görmektedir. Yaş ile kader seçeneği arasında doğrusal bir ilişki vardır, yaş arttıkça tarım işçiliğini kader olarak görme oranları da artmaktadır. Genç çalışanlar, tarım işçiliğini yapacak başka bir olmadığı için çalışılan yer olarak görmektedirler.

Katılımcıların yaşı ile tarım işçisi olmaktan memnun olma durumları arasındaki ki-kare test sonuçları Çizelge 9'da verilmiştir. Buna göre yaş ile memnuniyet arasında istatistiki olarak bir anlamlılık mevcut olup, önem derecesi $p<\% 1^{\prime}$ dir.

Çizelge 9. Yaş ile tarım işçisi olmaktan memnun olma durumu test istatistiği

Table 9. Test statistics of age and being satisfied with being an agricultural worker

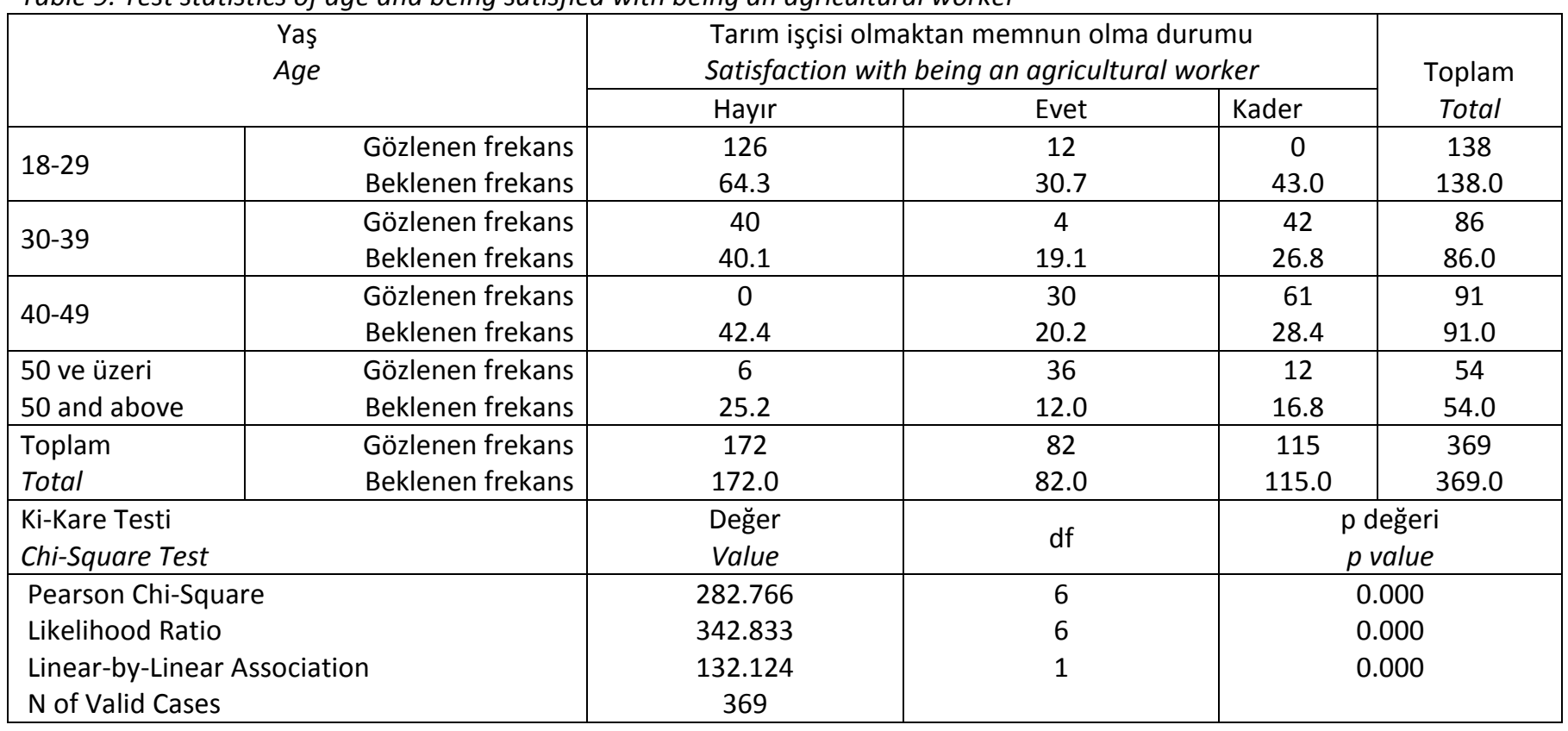


Genç yaş grubunda olanların \%91.3'ü tarım işçisi olmaktan memnun değildir. Yaş arttıkça tarım işçiliğinden memnun olma oranı ya da kader olarak görme oranları da artmaktadır. Burada en dikkat çeken yaş grubu, 40-49 yaş aralığı olup, bunların tamamı evlidir ve tarım iş̧̧isi olmaktan memnuniyetsizlik duymamaktadırlar. Bu durum bölgenin ataerkil, bağımlı ve sosyo-ekonomik yapısıyla, eğitim seviyesinin düşüklüğü ile açıklanabilmektedir. Katılımcıların yaşı ile eğer tarım işçisi olmasıydı ne olmak veya yapmak isterdi (beklenti) arasındaki ki-kare test sonuçları Çizelge $10^{\prime}$ da verilmiştir. Sonuçlara göre yaş ile beklenti arasında istatistiki olarak bir anlamlılık mevcut olup, önem derecesi $p<\% 1$ 'dir.

Çizelge 10. Yaş ile beklenti arasındaki test istatistiği

Table 10. Test statistics between age and expectation

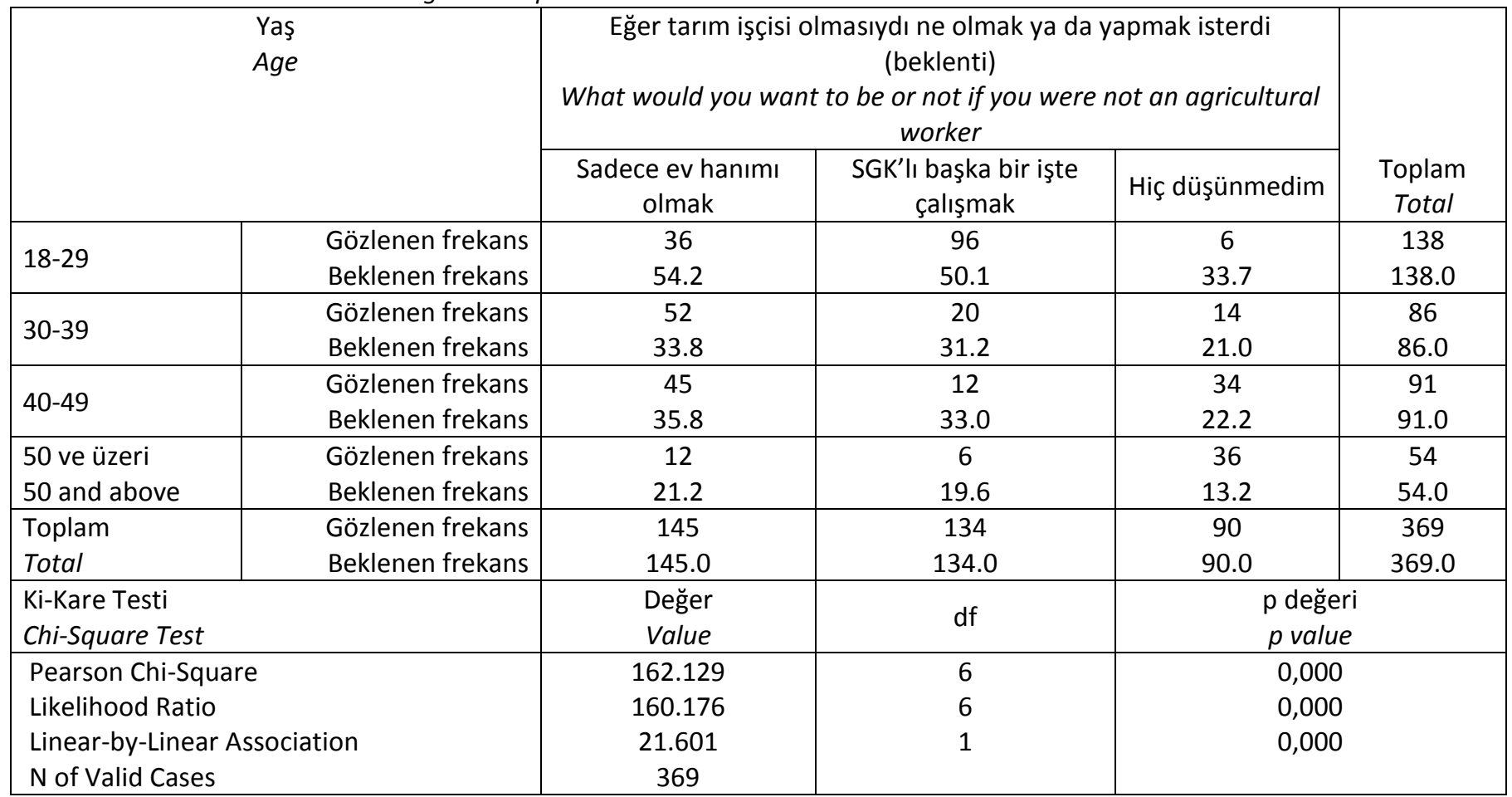

Genç yaş grubunda yer alanların \%69.6'sı SGK'lı bir işte çalışmak isterken, 40-49 yaş grubunda yer alanların \%49.5' $\mathrm{i}$ sadece ev hanımı olmak istediklerini belirtmişlerdir. Katılımcıların \%24.4'ü bunu hiç düşünmediklerini, aslında bunu kader olarak gördüklerini belirtmişlerdir. Yaş arttıkça, hiç düşünmedim diyenlerin oranı da artmaktadır. Yaş ile SGK'lı bir işte çalışmak isteyenler arasında, ters orantı vardır. Yaş arttıkça, SGK'lı bir işte çalışma beklentisi ve düşüncesi de azalmaktadır. $\mathrm{Bu}$ sonuçlar araştırma öncesi beklentiler ile de örtüşmektedir.

\section{Sonuçlar}

Ülkemizde, kadınların işgücüne katılım oranları düşük olup, bunda etkili olan önemli faktörler arasında yaş, medeni durum ve eğitim yer almaktadır (Başlevent ve Onaran, 2003; Kızılgöl, 2012; Kılıç ve Öztürk, 2014; Yazıcı, 2018). Diğer taraftan, ağır ve kötü çalışma koşulları, cinsiyete dayalı düşük ücret, kadınların işgücüne katılımlarını ve memnuniyetlerini etkilemektedir (Makal, 2010; Kılıç ve Öztürk, 2014). Ülkemizde kadın iş gücü halen tarımın en önemli girdilerinden biridir. Tarımsal üretimin temel taşlarından olan kadın çalışanlar, tarım işçisi olmaktan dolayı memnun değildirler. İş memnuniyeti, bakış ve beklenti ile medeni durum, eğitim ve yaş arasında istatistiki olarak yüksek anlamlı ( $p<\% 1$ ) bir ilişki vardır. Bekâr olanlar, genç yaş grubunda yer alanlar ile ortaokul ve lise mezunları tarım işçiliğinden en fazla memnuniyetsizler olup, bunlar daha çok SGK'। başka bir işte çalışmak istemektedirler. Bunun temel sebepleri arasında, ağır iş koşulları, ücretsiz 
aile iş gücü olması ya da düşük ücret ile sosyal güvenlik haklarından yoksun olmaları yatmaktadır. Ülkemizde tarımda çalışan kadınların $\% 90$ 'dan fazlası kayıt dışı ve sosyal güvenlik kapsamı dışında olmaları nedeniyle her türlü riske açıktırlar. Şanlıurfa'da tarımda çalışan kadınların \%35'i sosyal güvenliğin ne anlama geldiğini dahi bilmemekte olup, yaklaşık \%11'i bunun bir çeşit devlet koruması olduğunu düşündüklerini belirtmişlerdir (Cançelik ve ark., 2017).

Dünya nüfusunun yarısını oluşturan kadınlar, dünyadaki toplam üretimin 2/3'ünü üretmelerine rağmen, toplam gelirin sadece \%5'ini alabilmektedirler (Peker ve Kubar, 2012). Ülkemizde tarım sektörünün GSYiH içindeki payının düşük ve istihdam içindeki payının yüksek olması, tarımsal üretimdeki verim düşüklüğünü, ekonomik örgütlenmedeki yetersizliği, kırsal alanda eğitim, sağlık gibi sosyal imkânların azlığı ve kaynakların etkin kullanılmamasının sonucu olarak ortaya çıkmaktadır (Keskin ve ark., 2017). Ülkemizde sayıları yüzbinlerle ifade edilen, kırsal da yaşayan ve çalışan kadınlar kendi adlarına girişimci olamamaktadırlar. Kendi hesabına çalışan veya işveren konumundaki kadın oranı \%5 civarında olup, tarımda çalışan ve kırsalda yaşayan kadınlar arasında, tarım veya tarım dışı girişimcilik oranı ise binde 1 civarındadır (Gülçubuk, 2017). Ülkemiz de genel olarak kırsalda eğitim seviyesi düşüktür. Şanlıurfa'da çiftçilerin ortalama eğitim süresinin 7 yıl civarında olduğu belirlenmiştir (Aydoğdu, 2017). Kırsalda kadınların eğitim seviyeleri daha da düşüktür. Ülkemiz nüfusunun yarısını oluşturan kadınların birçok alanda karşılaştığı sorunlar ve engeller nedeniyle, kadın emek sömürüsüne maruz kalmakta, bu durum onları yoksullaştırmaktadır. Yoksulluk tarımdaki, kırsaldaki kadınlar arasında daha da yaygınlaşmaktadır (Gülçubuk, 2017).

Ülkemizde son dönemlerde kadınlara yönelik olarak oluşturulan politikalar ve uygulamalar daha çok kentte yaşayan kadınlarla sınırlı kalmaktadır. Kırsalda ve tarımda çalışan kadınlara yönelik, örgütlenme başta olmak üzere, pozitif ayrımcılık içeren özel politikalar geliştirilmeli ve uygulanmalıdır. Katılımcıların önemli bir kısmı
SGK'lı başka bir işte çalışmak istediklerini belirtmişlerdir. Aslında bu kırsaldan kente doğru göç etme istediğidir. Göç, tarımsal üretimde çalışacak işgücünün azalması, tarımda üretim ve verimin düşmesi, kırsal yoksulluğun artması gibi birçok sorunu da beraberinde getirmektedir (Yalçın ve Kara, 2016). Kırsal da yaşayan ve çalışan kadınların, yaşam standartlarının yükseltilmesini sağlayacak, sosyal ve ekonomik yapılarının iyileştirilmesi ve arttırımasına yönelik uygulamalar fazlalaştırılmalıdır. Tarımsal üretimin esas unsurlarından olan kadının kırsal da, üretimde yer alması, kırsaldan kente doğru yaygınlaşan göç sorunun çözümüne de katkı sağlayacaktır.

\section{Kaynaklar}

Arıkan, G. (1988). Kırsal kesimde kadın olmak. Hacettepe Üniversitesi Edebiyat Fakültesi Dergisi, 5(2), 1-16.

Aydogdu, M. (2017). Evaluation of farmers' willingness to pay for agricultural extension services in GAP-Harran Plain, Turkey. Journal of Agricultural Science and Technology, 19(4), 785-796.

Başlevent, C., and Onaran, O. (2003). Are Turkish wives more likely to become addedor discouraged workers? Labour, 17(3), 439-458.

Bayram, N. (2015). Sosyal Bilimlerde SPSS ile Veri Analizi. Bursa: Ezgi Kitapevi.

Berber, M., ve Eser, B. Y. (2008). İş, Güç. Endüstri Illişkileri ve insan Kaynakları Dergisi, 10(2), 1-16.

Biçerli, M, K. (2000). Çalışma Ekonomisi. İstanbul: Beta Basım A.Ş.

Cançelik, M., Aydoğdu, M. H., Sert, M., Sevinç, M. R., Eren, M. E., ve Mancl, A. R. (2017). A research on the satisfaction of working conditions of women employee in rural areas: Şanlıurfa sampling-Turkey. IBANESS, International Balkan and Near Eastern Social Sciences Conference Series, March 4-5, 677683s. Edirne.

Dikmen, A. A. (1995). Kamu Çalışanlarında iş doyumu ve yaşam doyumu. (Yayımlanmamış yüksek lisans tezi). Ankara Üniversitesi Sosyal Bilimler Enstitüsü, Ankara.

Eğinli, A. T. (2009). Çalışanlarda iş doyumu: kamu ve özel sektör çalışanlarının iş doyumuna yönelik bir araştırma. Atatürk Üniversitesi iktisadi ve Idari Bilimler Dergisi, 23(3), 35-52.

Gökdemir, L., ve Ergün, S. (2012). Kırsal kalkınmada kadının rolü. Inönü Üniversitesi Uluslararası Sosyal Bilimler Dergisi, 1(1), 67-80.

Gülçubuk, B. (2017). Tarımda kadının kendisi var ama adı yok. Erişim Adresi: https://businessht.bloomberght.com/yorum/haber/ 1164163-tarimda-kadinin-kendisi-var-ama-adi-yok (Erişim Tarihi: 25.02.2019)

Günkör, C. (2017). Eğitim ve kalkınma ilişkisinin incelenmesi. 
Uluslararası Sosyal Bilimler Eğitimi Dergisi, 3(1), 1432.

Keskin, G., Kaplan, G., ve Başaran, H. (2017). Türkiye'de aile çiftçiliği, işgücü prodüktivitesi ve sürdürülebilirlik. Harran Tarım ve Gıda Bilimleri Dergisi, 21(2), 209218.

Kılıç, D., ve Öztürk, S. (2014). Türkiye'de kadınların işgücüne katılımı önündeki engeller ve çözüm yolları: bir ampirik uygulama. Amme Idaresi Dergisi, 47(1), 107130.

Kızılgöl, Ö. (2012). Kadınların işgücüne katılımının belirleyicileri: ekonometrik bir analiz. Doğuş Üniversitesi Dergisi, 13(1), 88-101.

Lorcu, F. (2015). Örneklerle Veri Analizi SPSS Uygulamalı. Ankara: Detay Yayıncılık.

Makal, A. (2010). Türkiye'de Erken Cumhuriyet Döneminde kadın emeği. Çalışma ve Toplum, 2, 13-40.

Orhunbilge, N. (2000). Tanımsal Istatistik Olasılık ve Olasılık Dağılımları. İstanbul: Avcıol Basım Yayın.

Özbekmezci, Ş., ve Sahil, S. (2004). Mevsimlik tarım işçilerinin sosyal, ekonomik ve barınma sorunlarının analizi. Gazi Üniversitesi Mühendislik Mimarlık Fakültesi Dergisi, 19(3), 261-274.

Peker, A. E. ve Kubar, Y. (2012). Türkiye'de kırsal kesimde kadın istihdamına genel bir bakış. Afyon Kocatepe Üniversitesi, iiBF Dergisi, 14(2), 173-188.

Pınar, F. (2008). Barbara Frischmuth'ta Çalışan Kadının Sorunları ve Kültürel ilişkiler. (Yayınlanmamış yüksek lisans tezi), Yüzüncü Yıl Üniversitesi Sosyal Bilimler Enstitüsü, Van.

TUik. (2018a). Türkiye İstatistik Kurumu, İstatistiklerle
Kadın, 2017. Erişim Adresi: http://www.tuik.gov.tr/PreHaberBultenleri.do?id=27 594 (Erişim Tarihi: 03.03.2019).

TUiK. (2018b). Türkiye İstatistik Kurumu, Adrese Dayalı Nüfus Kayıt Sistemi Sonuçları, 2017. Erişim Adresi: http://www.tuik.gov.tr/PreHaberBultenleri.do?id=27 587 (Erişim Tarihi: 01.02.2018).

TUik. (2019a). Türkiye İstatistik Kurumu, İş gücü İstatistikleri. Erişim Adresi: www.tuik.gov.tr (Erişim Tarihi: 25.02.2019).

TUiK. (2019b). Türkiye İstatistik Kurumu, İstihdam edilen yıllar ve cinsiyete göre işteki durumu. Erişim Adresi: http://tuik.gov.tr/PreTablo.do?alt_id=1007 (Erişim Tarihi: 02.03.2019).

TZOB. (2018). Türkiye Ziraat Odaları Birliği, Dünya Kadın Çiftçiler Günü, Erişim Adresi: https://ekmekvegul.net/gundem/tarimda-calisankadinlarin-yuzde-90i-kayit-disi (Erişim Tarihi: 26.02.2019).

Ünüvar, P., ve Tagay, Ö. (2015). Çalışan evli kadınların toplumsal cinsiyet rolleri, yaşam, iş doyumu ve evlilik uyumlarının incelenmesi. Kadın/Woman 2000, 16(1), 21-44.

Yazıcı, A. M. (2018). Medeni durumun ve eğitimin kadınların işgücüne katılımına etkisi: Tüik verileri üzerine ampirik bir çalışma. Iktisat Politikası Araştırmaları Dergisi, 5(2), 101-116.

Yalçın, G. ve Öcal Kara, F. (2016). Kırsal göç ve tarımsal üretime etkileri. Harran Tarım ve Gıda Bilimleri Dergisi, 20(2), 154-158. 